\title{
TARGET SPECIES OF ARTISANAL FISHERIES AND THEIR CONSERVATION STATUS IN TWO FISHING VILLAGES IN THE ATLANTIC: PENICHE (PORTUGAL) AND ARRAIAL DO CABO (BRAZIL)
}

\author{
ESPÉCIES ALVO DA PESCA ARTESANAL E SEU STATUS DE CONSERVAÇÃO EM \\ DUAS VILAS DE PESCADORES NO ATLÂNTICO: PENICHE (PORTUGAL) E ARRAIAL \\ DO CABO (BRASIL)
}

\author{
*Heitor O. Braga ${ }^{1,2}$, Miguel A. Pardal ${ }^{2}$, Joelson Musiello-Fernandes ${ }^{4}$, Ulisses M. Azeiteiro ${ }^{1}$
}

\begin{abstract}
${ }^{1}$ Department of Biology \& CESAM - Centre for Environmental and Marine Studies, University of Aveiro, 3810-193, Aveiro, Portugal.; ${ }^{2}$ CAPES Foundation, Ministry of Education of Brazil, Brasília - DF, Brazil.; ${ }^{3}$ Centre for Functional Ecology, Department of Life Sciences, University of Coimbra, Calçada Martins de Freitas, 3000-456, Coimbra, Portugal.; ${ }^{4}$ Center for Human and Natural Sciences, Postgraduate Program in Environmental Oceanography, Federal University of Espírito Santo; * Correspondence author: Heitor de Oliveira Braga *heitorob@ua.pt; Miguel Ângelo Pardal - mpardal@uc.pt.; Joelson Musiello-Fernandesjoelson.pesca@gmail.com; Ulisses Miranda Azeiteiro - ulisses@ua.pt.
\end{abstract}

\begin{abstract}
This study shared the fishers' local ecological knowledge (LEK) from the two fishing villages (Peniche, Portugal, and Arraial do Cabo, Brazil), based on answers to the following key question: What are the main target species for fishing in Peniche/Arraial do Cabo? A total of 221 semi-structured interviews were conducted in the Atlantic fishing villages during 2016. Fisher's interviews reported 42 species of marine animals from Peniche fishing community, and 40 species in Arraial do Cabo. The fisheries resources cited by fishers were assessed for vulnerability, according to the issue's conservation based in IUCN and Brazilian Red List. We have identified the main target species for artisanal fishing in both fishing villages. The species with some degree of vulnerability included in the list of fishers in Peniche were: T. trachurus and P. glauca. In Arraial do Cabo fishing village this list is formed by nine species: $P$. saltatrix, E. marginatus, $M$. bonaci, $P$. glauca, $M$. canis, H. flavolimbatus, H. niveatus, G. galeus and P. americanus - Brazilian Subpopulation. These data acquired through the artisanal fishers of these communities can be an essential starting point for the design of future additional research on the conservation of local biological resources. Monitoring the artisanal fisheries through the informal data shared in this study can contribute to more appropriate and integrated management of the marine resources.
\end{abstract}

Keywords: Marine fauna, Sea social-ecological system, Artisanal fishers, Ethnobiology.

RESUMO: Este estudo compartilhou o conhecimento ecológico local dos pescadores (CEL) de duas vilas artesanais (Peniche, Portugal e Arraial do Cabo, Brasil), com base em respostas à seguinte pergunta-chave: Quais são as principais espécies-alvo da pesca em Peniche/Arraial do Cabo? Em 2016 foram realizadas 221 entrevistas semiestruturadas nas comunidades pesqueiras atlânticas amostradas. As entrevistas com os pescadores relataram 42 espécies de animais marinhos na comunidade pesqueira de Peniche e 40 espécies em Arraial do Cabo. Os recursos pesqueiros citados pelos pescadores foram avaliados quanto à vulnerabilidade, de acordo com as questões de conservação baseadas na IUCN e no Livro Vermelho da Fauna Brasileira Ameaçada de Extinção. Identificamos as principais espécies-alvo para a pesca artesanal em ambas as aldeias de pescadores. As espécies com algum grau de vulnerabilidade incluídas na lista de pescadores de Peniche foram: T. trachurus e P. glauca. Na vila pesqueira de Arraial do Cabo, esta lista é composta por nove espécies: P. saltatrix, E. marginatus, $M$. bonaci, P. glauca, M. canis, H. flavolimbatus, H. niveatus, G. galeus e P. americanus - Subpopulação brasileira. Esses dados adquiridos através dos pescadores artesanais destas comunidades podem ser visualizados como um ponto de partida essencial para o delineamento de futuras pesquisas adicionais acerca da conservação de recursos biológicos locais. Os monitoramentos da pesca artesanal através dos dados informais compartilhados neste estudo podem também contribuir para uma gestão mais apropriada e integrada dos recursos marinhos.

Palavras-chave: Fauna marinha, Sistema socio-ecológico marinho, Pescadores artesanais, Etnobiologia. 


\section{INTRODUCTION}

Fishing is a very comprehensive activity, with around 40.3 million people involved in the production of approximately 171 million tons of fish worldwide (FAO, 2018). It relates to food security, as it provides a crucial source of animal protein, and acts as a source of income, providing employment opportunities and thus directly assisting in reducing poverty (ALLISON and ELLIS, 2001; BÉNÉ, 2006). This socioeconomic activity also shows a clear role and an essential place in food and nutrition policies (HICKS et al., 2019). Small scale fisheries are not only vital for local consumption, but they can also provide national and international commercial activities and provide income to support different economic markets (POMEROY et al., 2020). Artisanal fisheries differ from other modalities (e.g., industrial fisheries) because they have low capital investment, low range of action, and simple technological apparatus (OLIVEIRA JÚNIOR et al., 2016; ROUSSEAU et al., 2019).

Fishing communities maintain a parental relationship with the environment, built over the years, which allows for sustainable exploitation of local marine fauna, thus ensuring the maintenance of social and cultural systems (ALVES and SOUTO 2015; DEEPANANDA et al. 2016). Small scale fishers have an in-depth knowledge of the occurrence and distribution of marine resources as a result of this direct and routine contact with the environment, which has been transmitted orally among community members (BERKES, COLDING and FOLKE, 2008). This set of wisdom is labeled as local ecological knowledge (LEK) because it concerns the relationships that living beings have with each other and with the environment where they inhabit, linked with a historical and cultural continuity in the use of resources (OLSSON and FOLKE, 2001). In this sense, LEK ends up associating older people with more experience within a certain local social community (DAVIS and WAGNER, 2003).

Studies related to the fishers' LEK have several purposes from social and cultural valorization and can serve as an important tool in the elaboration of management measures among fishers and managers (BRAGA et al., 2018a; MEDEIROS et al., 2018; MUSIELLO-FERNANDES, ZAPPES and HOSTIM-SILVA, 2017; PEÑAHERRERA-PALMA et al., 2018; SILVANO and BEGOSSI, 2016). The inclusion of LEK is still an exception rather than a rule, since it is generally not used for managing fishery resources (JOHANNES, FREEMAN and HAMILTON, 2008; ZAPPES et al., 2016). However, the inclusion of this set of knowledge in some parts of the world shows a satisfactory result with the reduction of conflicts over the use of fishing resources in traditional fishing villages (ESPINOZA-TENORIO et al., 2013; POMEROY et al., 2007).

Artisanal fishing exploits marine resources intensely, despite the lower catch capacity when compared to industrial fisheries. This impact occurs on fish species directly used, as well as on marine biodiversity, causing significant effects on marine ecosystems around the world (PAULY, HILBORN and BRANCH, 2013). Thus, to maximize the effectiveness of fisheries management, especially in traditional communities, it is necessary to combine data from different sources of information, which can expand the results and lead to quick and low-cost response (BEVILACQUA et al., 2016). In this perspective, there is a gap in the literature on studies that seek to systematize target species from artisanal fisheries in Portugal and Brazil (BEVILACQUA et al., 2016; BIRÓ et al., 2014; BRAGA et al., 2017, 2019; BRAGA, PARDAL and AZEITEIRO, 2018b), which may be prone to extinction. Therefore, this study aimed to share through ethnobiology tools, the primary target resources of marine fishing used by different fishing villages located in two countries (Brazil and Portugal) in different Atlantic and socio-ecological systems.

\section{METHODS}

\section{Study site and ecological context}

The study was carried out in two fishing villages from Brazil and Portugal. One of the traditional fishing community is located on the coast of Arraial do Cabo (22 $\left.57^{\prime} 57^{\prime \prime} \mathrm{S}, 42^{\circ} 01^{\prime} 41^{\prime \prime} \mathrm{W}\right)$, within the limits of the Marine Extractive Reserve (MER) of Arraial do Cabo, State of Rio de Janeiro, Brazil (Figure 1). The other fishing village belongs to the municipality of Peniche $\left(39^{\circ} 21^{\prime} 32^{\prime \prime} \mathrm{N}, 9^{\circ} 22^{\prime} 40^{\prime \prime} \mathrm{W}\right)$, near to the Berlengas Marine Natural Reserve (MNR), Leiria District, Portugal.

In the Southern Hemisphere, the MER of Arraial do Cabo is known for its high biological diversity (FISCHER et al., 2015), due mainly to the strong influence of a coastal upwelling annually linked to local bathymetry and wind regime (CARBONEL, 2003). In the Northern Hemisphere, the Berlengas 
MNR consists of an insular ecosystem with a considerable marine biological value in the surrounding areas and great importance in both botanical and ornithological terms (FERNANDES et al., 2016).

The fishing community of Arraial do Cabo has about 1.000 active fishermen (GIGLIO et al., 2017), while in Peniche the number of active fishers reaches 996 (BRAGA et al., 2017). Even in different social and geographical contexts, the primary goal of both study sites is the sustainable use and conservation of the natural resources by local dependent communities, which are mainly represented by these artisanal fishers (BRAGA, PARDAL and AZEITEIRO, 2018b; ICMBIO, 2019).

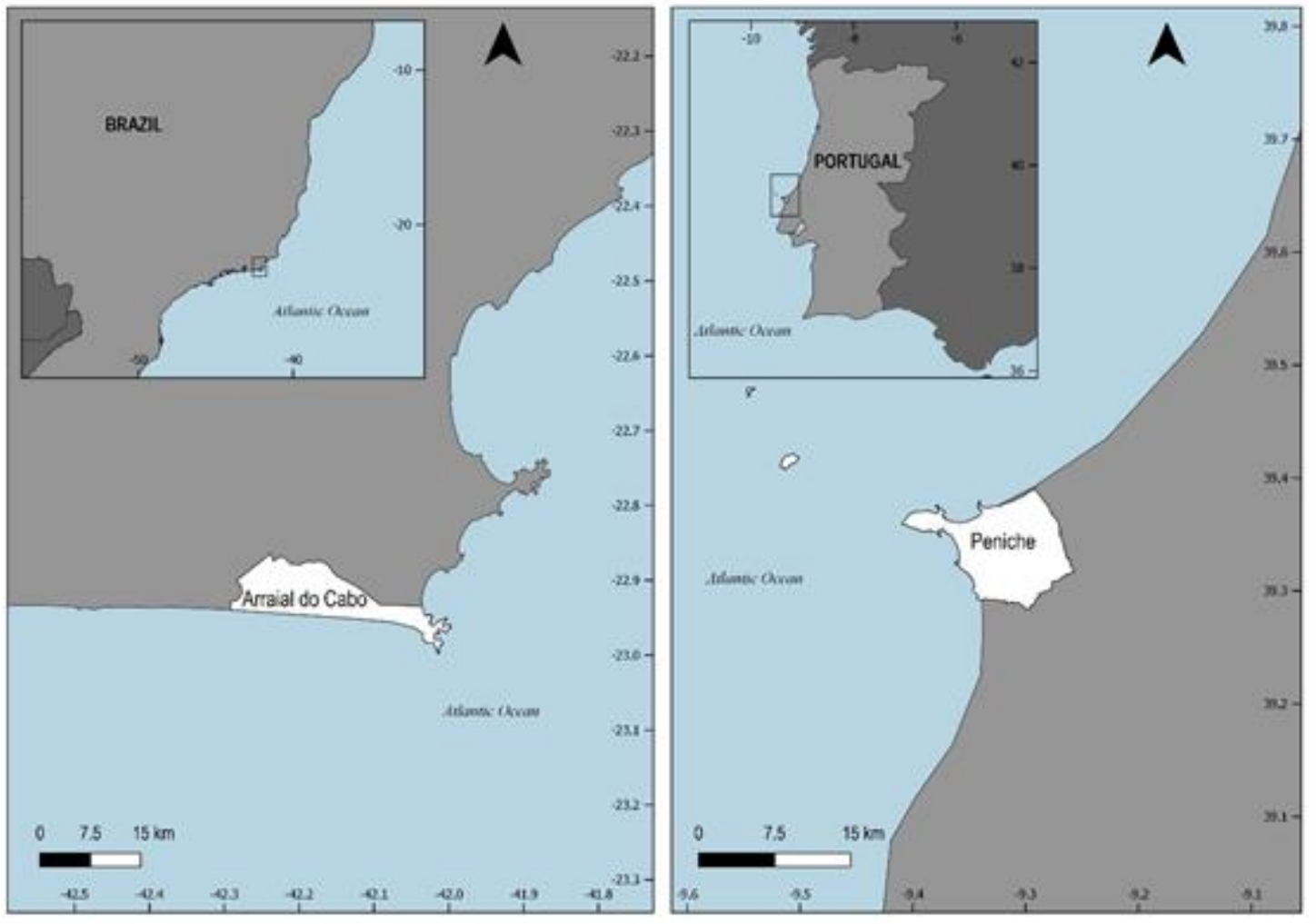

Figure 1: The fishing village of Arraial do Cabo, Rio de Janeiro State, Brazil, and the fishing village of Peniche, Portugal.

\section{Data collection}

Preliminary visits were made to both communities (mainly in fishing ports) as a way to create a trustworthy ambiance (BROOK and MCLACHLAN, 2008), and to initially extract information from artisanal fishermen following the "data generating methodology" (POSEY, 1987). The time of data collection in both communities was effectively the same, not influencing these findings. These events occurred in April 2016 in Arraial do Cabo, and then in June 2016 in Peniche. After this initial phase, the semi-structured interview script (ALBUQUERQUE et al., 2014) was conducted with members of these fishing communities between April and September 2016. The approach was always carried out in the fishing ports of both sampled cities during the arrivals and departures of the fishing boats or on the beaches of high fishing activity. Interviews were documented using mostly manual transcription, and occasionally a digital voice recorder. Semi-structured interviews were applied based on the fishers' profile (age, fishing experience, income, and education level), and the key question: What are the main target species for fishing in Peniche / Arraial do Cabo? In this regard, fishers were induced to cite as many target marine species as possible in both communities. A Free Listing technique was used in order to identify those items in social domains that tend to be more prominent or locally salient (ALBUQUERQUE et al., 2014).

In Brazil, the research was approved by the Ethics Committee of the Federal University of Rio de Janeiro State, (protocol CAAE: 53819116.6.0000.5285), while in Portugal this kind of research approval is not necessary. The Biodiversity Information and Authorization System (SISBIO) has granted permission for scientific activity within the Arraial do Cabo MER (Number: 52333-1). The researcher also previously requested authorization for "Docapesca - Portos e Lotas" to obtain free access to the fishing port of Peniche, Portugal. 


\section{Data analyses}

The total set of information provided by the interviewed fishermen was taken into account, since the model of union of the various individual competences was used (MARQUES, 2001), and the congruence test was made through a matrix of comparative cognition (COSTA-NETO and MARQUES, 2000). Data were analyzed through an emic-etic perspective, comparing academic knowledge with informal knowledge (HARRIS, 1976).

The data of the species followed the databases Integrated Taxonomic Information System (ITIS, 2018) and the IUCN Red List of Threatened Species (IUCN, 2019). The analyzes also considered the data from Brazil Red Book of Threatened Species of Fauna (ICMBIO, 2018). By convention, only the species mentioned by at least $5 \%$ of respondents in Peniche and Arraial do Cabo were analyzed and highlighted in the results. We discuss only those species that show some degree of vulnerability according to the lists mentioned above. Descriptive statistics were used to measure fisher's averages, standard deviation, and percentages in general through the R Project for Statistical Computing version 4.0.2 (TEAM, 2020).

\section{RESULTS AND DISCUSSION Informants' profile}

This study was based on 221 interviews (Table 1) conducted with fishers from Peniche $(\mathrm{N}=87)$ and from Arraial do Cabo $(\mathrm{N}=134)$. Even with a numerical composition of similar fishers, about $35 \%$ more interviews were conducted in Arraial do Cabo, Brazil. The number of fishers interviewed in both villages in our study was sufficient to answer our questions (BRAGA et al., 2018a, 2017). The average age of the interviewees was 52.41 years old $(\mathrm{sd}=13.4)$, and the fishing experience time was 31.81 years $(\mathrm{sd}=13.2)$. In Peniche the average of the interviewees was of 58.3 years $(\mathrm{sd}=10.6)$ and is about $16.5 \%$ greater than of Arraial do Cabo that was of 48.6 years $(\mathrm{sd}=13.6)$. The fishing experience was 39.0 years $(\mathrm{sd}=10.9)$ in the Portuguese community and 27.1 years $(\mathrm{sd}=12.2)$ in the Brazilian village. The average income in Peniche (810.5 Euros) was approximately 1.9x higher than in Arraial do Cabo (420.5 Euros). In the two regions, most fishers studied between 1-5 years (Peniche $=67 \%$; Arraial do Cabo $=70 \%$ ). About $22 \%$ of fishers from Peniche and $19 \%$ from Arraial do Cabo showed a study time of 6 to 9 years, and $11 \%$ of the sample in both studied sites have 10 to 12 years of schooling.

Table 1: Fishers' profile in Arraial do Cabo, Rio de Janeiro, Brazil and Peniche, Leiria District, Portugal $(\mathrm{N}=221)$.

\begin{tabular}{lll}
\hline Number of interviews & Arraial do Cabo & Peniche \\
\hline Fishers' Variables & 134 & 87 \\
\hline Mean Age (years) & & \\
\hline Fishing experience (years) & $48.6( \pm 13.6)$ & $58.3( \pm 10.6)$ \\
\hline Income source (EUR) & $27.1( \pm 12.2)$ & $39.0( \pm 10.9)$ \\
\hline Education level (years of schooling) & 420.5 & 810.5 \\
\hline $1-5(\mathrm{~N}, \%)$ & & $58(67 \%)$ \\
\hline $6-9(\mathrm{~N}, \%)$ & $94(70 \%)$ & $19(22 \%)$ \\
\hline $10-12(\mathrm{~N}, \%)$ & $25(19 \%)$ & $10(11 \%)$ \\
\hline
\end{tabular}

The average age of the fishers in Peniche was superior and had a difference of approximately 9.7 years of that of Arraial do Cabo. This fact shows how this economic and traditional activity has been supported by older fishermen mainly in the Portuguese community. In Portugal, the aging of this workforce is mainly due to the European Union's legislative restrictions and low profitability in this sector (SANTOS et al., 2012). In developing countries, such as Brazil, the small-scale fisheries are competing with industrial fleets without adequate support from local public policies (PAULY and ZELLER, 2016). This evidence makes these fishermen seek other economic activities to meet their financial and functional difficulties in the work. In addition, these fishers begin to view fishing as an undesirable profession and thus influence their children to seek a more profitable, valuable income (TRIMBLE and JOHNSON, 2013).

The average fishing experience was over 27 years in the communities sampled, which shows the vast dependence of these communities on fishing resources for family income. In both fishing villages, the educational level is concentrated in the range of 1-5 years of schooling. This tendency of low 
schooling among coastal fishermen is also observed in other fishing communities in Brazil (ABREU, DOMIT and ZAPPES, 2017; AWABDI et al., 2018; MUSIELLO-FERNANDES, ZAPPES and HOSTIM-SILVA, 2018) and Portugal (SILVA et al., 2018). Finally, this low level of education may be strongly related to the low productivity of these fishermen, which can therefore also affect the income of these individuals (WEKKE and CAHAYA, 2015).

\section{Peniche fishing village}

\section{The target species of fishing}

A total of 42 folk names of marine species were cited by fishers, including 39 fish species, two marine mollusks of the Cephalopoda class (squid and octopus), and one shellfish "mariscos" (the mix of various species of invertebrate marine animals). We obtained 14 folk names of marine fish species cited by at least $5 \%$ of artisanal fishers in the village of Peniche in Portugal (Table 2). The main fishing targets were the European pilchard (Sardinha; $\mathrm{N}=57$ ), Horse mackerel (Carapau in general; $\mathrm{N}=43$ ), Chub mackerel (Cavala; $\mathrm{N}=40$ ) and Conger eel (Safio; $\mathrm{N}=22$ ) (Table 2). The other marine species mentioned in the community of Peniche that deserved prominence were: Wreckfish (Chernelegítimo; $\mathrm{N}=15$ ), Black scabbardfish (Espada-preto; $\mathrm{N}=13$ ); Forkbeard (Abrótea-da-costa; $\mathrm{N}=10$ ), Raja rays nei (Raias; $\mathrm{N}=10$ ), Red porgy (Pargo-legítimo; $\mathrm{N}=10$ ) and Common octopus (Polvo comum; $\mathrm{N}=9$ ), Swordfish (Espadarte; $\mathrm{N}=7$ ), Blackbelly rosefish (Cantarilho; $\mathrm{N}=6$ ), European hake (Pescada-branca; $\mathrm{N}=6$ ), and Blue shark (Tubarão azul or Quelha; $\mathrm{N}=6$ ).

Table 2: Cognition compared to folk names $(\mathrm{N}=14)$ most cited by fishers and the scientific names (Linnaean) of the target species in Peniche, Portugal.

\begin{tabular}{lllll}
\hline Family & $\begin{array}{l}\text { Common Names } \\
\text { (English) }\end{array}$ & $\begin{array}{l}\text { Folk names } \\
\text { (Portuguese) }\end{array}$ & Scientific names & $\begin{array}{l}\text { N of } \\
\text { mentions }\end{array}$ \\
\hline Clupeidae & $\begin{array}{l}\text { European } \\
\text { pilchard }\end{array}$ & Sardinha & Sardina pilchardus (Walbaum, 1792) & 57 \\
\hline Carangidae & Horse mackerel & Carapau & Trachurus trachurus (Linnaeus, 1758) & 43 \\
\hline Scombridae & Chub mackerel & Cavala & Scomber japonicus Houttuyn, 1782 & 40 \\
\hline Congridae & Conger eel & Congro/Safio & Conger conger (Linnaeus, 1758) & 22 \\
\hline Polyprionidae & Wreckfish & Cherne-legítimo & Polyprion americanus (Bloch \& Schneider, & 15 \\
\hline Trichiuridae & Black & Espada-preto & Aphanopus carbo Lowe, 1839 & 13 \\
\hline Phycidae & Forkbeard & Abrótea-da-costa & Phycis phycis (Linnaeus, 1766) & 10 \\
\hline Rajidae & Raja rays nei & Raia & Raja spp. & 10 \\
\hline Sparidae & Red porgy & Pargo-legítimo & Pagrus pagrus (Linnaeus, 1758) & 10 \\
\hline Octopodidae & Common octopus & Polvo-vulgar & Octopus vulgaris Cuvier, 1797 & 9 \\
\hline Xiphiidae & Swordfish & Espadarte & Xiphias gladius Linnaeus, 1758 & 7 \\
\hline Sebastidae & Blackbelly & & Helicolenus dactylopterus (Delaroche, & 6 \\
\hline Merlucciidae & European hake & Pescada-branca & Merluccius merluccius (Linneaus, 1758) & 6 \\
\hline Carcharhinidae & Blue Shark & $\begin{array}{l}\text { Tubarão azul/ } \\
\text { quelha/Tintureira }\end{array}$ & Prionace glauca (Linnaeus, 1758) & 6 \\
\hline & & & & \\
\hline
\end{tabular}

\section{Conservation status of the most critical fishing targets}

According to the International Union for Conservation of Nature (IUCN) (Table 4), the species $S$. pilchardus, S. japonicus, C. conger, P. phycis, Raja spp., P. pagrus, X. gladius, H. dactylopterus and M. merluccius were classified as Least Concern (LC), not presenting any degree of threat.

The horse mackerel, Trachurus trachurus (Linnaeus, 1758), is the only marine species classified as Vulnerable (VU) among the target species of Peniche according to the fishermen's citations, indicating that this animal is presenting a high risk of extinction in the wild. T. trachurus in the Portuguese fishing community (Peniche) is the only species classified as "vulnerable" according to the last classification available by the IUCN (IUCN, 2019). The catches of horse mackerel in the 1990s exceeded 500,000 tons, arriving in the early 2000s at 250,000 tons, which demonstrates the importance of this natural resource for the economy of coastal communities throughout the ages (ABAUNZA et al., 2008). The INE (Portuguese National Statistics Institute) in 2013 reported an increase of about $7.3 \%$ in the volume of discharges of this fish carried out by Producer's Organizations (PO) in Portugal. The data of fish landings in Portugal was of 17.597 tons in that same year, being among the three most loaded of the country (INE, 2014). Already in the statistical bulletin in 2017 (2018 Edition), the researchers showed a drop of about 19.7\% of the volume of discharges of this fish (INE, 2018). In the latest National Statistic (2017), horse mackerel in Portugal has shown a 
positive evolution in relation to the state of exploitation by the fleet in national waters, which makes the situation a little less worrying in this area that embraces Peniche (INE, 2018). In our findings in the Peniche fishing village, the horse mackerel was the second most frequently mentioned by the artisanal fishermen of this region $(\mathrm{N}=43)$, behind only the sardine $(\mathrm{N}=57)$. This fact is in line with the information provided by INE mentioning mackerel, horse mackerel, and sardines as the main species in the volume of fish unloaded in Portugal with purse seine fleet. In a global set only within this fishing gear, there was a decrease from $42.9 \%$ to $37.9 \%$ in 2017 of the nominal catches of fresh fish by fishing gear in Portugal. This is due to the decrease in fishing for marine fish, such as mackerel $(-40.7 \%)$ and horse mackerel $(-12.5 \%)$. Unlike the previous six years and unlike these species, sardines had a $9 \%$ increase over the same period (INE, 2018).

The Blue shark Prionace glauca (Linnaeus, 1758) was included in the category Near Threatened (NT) according to the evaluation information of the IUCN Red List Category and Criteria. This shark is a predatory pelagic species, being in a state of great concern regarding its stocks and its fishing sustainability (VANDEPERRE et al., 2014). This shark species is one of the most exploited in the world, being found both in tropical and temperate waters in the seas worldwide (VERÍSSIMO et al., 2017). The IUCN expresses great concern about a possible population downward trend of this circumglobally species of shark (IUCN, 2019). One of the main target species of Peniche fishing was the shark (mentioned six times by local fishers). In Portugal, the blue shark is usually caught by the swordfish fishing fleet as bycatch (ALVES et al., 2016) and is mostly transacted in the auctions of the Portuguese municipalities of Viana do Castelo, Peniche, and Sesimbra. The main methods of catching this shark in these localities are through the trawl, gillnets, and longline fishery, and the target public in the commercialization of this product is the population in general (DOCA PESCA, 2018). Thus, as reported by the fishers of Peniche, we can point out that this fishing is probably occurring through bycatch. This fact is in line with the leading cause of the sharp decline in the population of blue shark in the oceans, which causes a significant concern with the conservation status of this species (MARTINS, 2013), together with the growing overfishing contributing to this current state of conservation of this species in recent decades (NYKÄNEN et al., 2018). However, there must always be a great deal of effort to raise fisher's awareness of better management of fisheries and the proper use of fishing gear as a means of minimizing by-catches and discards in fisheries (POISSON et al., 2019).

For $P$. americanus, data on its conservation status was classified as Data Deficient (DD), and in this case it is not necessarily a threat category. Finally, A. carbo and O. vulgaris were categorized as Not Evaluated (NE) as they have not yet been evaluated against the IUCN standard criteria. Lastly, we suggest that these species in their coverage locations have their conservation status investigated and analyzed so that there is a projection of the conservation status of these species in the world, and especially in Peniche. Information about the population stock of these fish species in their habitat may come to assist future guidelines and actions in favor of marine biodiversity conservation.

\section{Arraial do Cabo fishing village \\ The target species of fishing}

In Arraial do Cabo we recorded 40 folk names of marine species being 37 species of fish, two of cephalopods and one of shellfish. We obtained 19 folk names of marine fish species cited by at least $5 \%$ of artisanal fishers (Table 3), and the species that had the highest expressiveness of citations were: Bluefish (Anchova; $\mathrm{N}=106$ ), Squid (Lula; $\mathrm{N}=63$ ), Horse-eye jack (Xerelete; $\mathrm{N}=49$ ), Tuna (Bonito in general; $\mathrm{N}=46$ ), and Sardine (Sardinha in general; $\mathrm{N}=46$ ), Namorado sandperch (Namorado; $\mathrm{N}=$ 35), Largehead hairtail (Espada; $\mathrm{N}=28$ ), and Lebranche mullet (Tainha; $\mathrm{N}=26$ ). The other species with considerable emphasis were: Chub mackerel (Cavalinha; $\mathrm{N}=20$ ), Common dolphinfish (Dourado; $\mathrm{N}=18$ ), Crevalle jack (Xaréu; $\mathrm{N}=15$ ), Unicorn filefish (Raquete; $\mathrm{N}=11$ ), Atlantic bonito (Serra; N = 11), Sharks (Cação in general; N = 10), Red porgy (Pargo; N = 10), Atlantic bigeye (Mirassol, Olho-de-cão, Olhudo; $\mathrm{N}=10$ ). Finally, the Grouper in general (Garoupa; $\mathrm{N}=8$ ), two species of Amberjack fish (Olhete in general; $\mathrm{N}=8$ ), and Wreckfis, Yellowedge grouper, Snowy grouper (Cherne in general; $\mathrm{N}=7$ ). 
Table 4. Marine target species in Peniche and the conservation status according to the IUCN Red List of Threatened Species.

\begin{tabular}{ll}
\hline Fisher's target species in Peniche & IUCN Conservation status \\
\hline Sardina pilchardus & Least Concern (LC) \\
\hline Trachurus trachurus & Vulnerable (VU) \\
\hline Scomber japonicus & Least Concern (LC) \\
\hline Conger conger & Least Concern (LC) \\
\hline Polyprion americanus & Data Deficient (DD) \\
\hline Aphanopus carbo & Not Evaluated (NE) \\
\hline Phycis phycis & Least Concern (LC) \\
\hline Raja spp. & Least Concern (LC) \\
\hline Pagrus pagrus & Least Concern (LC) \\
\hline Octopus vulgaris & Not Evaluated (NE) \\
\hline Xiphias gladius & Least Concern (LC) \\
\hline Helicolenus dactylopterus & Least Concern (LC) \\
\hline Merluccius merluccius & Least Concern (LC) \\
\hline Prionace glauca & Near Threatened (NT) \\
\hline
\end{tabular}

Table 3: Cognition compared to folk names $(\mathrm{N}=19)$ most cited by fishers and the scientific names (Linnaean) of the target species in Arraial do Cabo, Rio de Janeiro State, Brazil.

\begin{tabular}{|c|c|c|c|c|}
\hline Family & $\begin{array}{l}\text { Common Names } \\
\text { (English) }\end{array}$ & $\begin{array}{l}\text { Folk names } \\
\text { (Portuguese) }\end{array}$ & Scientific names & $\begin{array}{c}\mathrm{N}^{0} \text { of } \\
\text { mentions }\end{array}$ \\
\hline Pomatomidae & Bluefish & $\begin{array}{l}\text { Anchova or } \\
\text { Enchova }\end{array}$ & Pomatomus saltatrix (Linnaeus, 1766) & 106 \\
\hline Loliginidae & $\begin{array}{l}\text { Arrow squid } \\
\text { Squid }\end{array}$ & Lula in general & $\begin{array}{l}\text { Doryteuthis (Doryteuthis) pleii } \\
\text { (Blainville, 1823) } \\
\text { Doryteuthis sanpaulensis (Brakoniecki, } \\
1084 \text { ) }\end{array}$ & 63 \\
\hline Carangidae & Horse-eye jack & Xerelete & Caranx latus Agassiz, 1831 & 49 \\
\hline Scombridae & $\begin{array}{l}\text { Skipjack tuna } \\
\text { Frigate tuna } \\
\text { Little tunny }\end{array}$ & Bonito in general & $\begin{array}{l}\text { Katsuwonus pelamis (Linnaeus, 1758) } \\
\text { Auxis thazard (Lacepède, 1800) } \\
\text { Euthynnus alletteratus (Rafinesque, } \\
1810 \text { ) }\end{array}$ & 46 \\
\hline Clupeidae & $\begin{array}{l}\text { Brazilian sardinella } \\
\text { Atlantic thread herring } \\
\text { False herring }\end{array}$ & Sardinha in general & $\begin{array}{l}\text { Sardinella brasiliensis (Steindachner, } \\
\text { 1879) } \\
\text { Opisthonema oglinum (Lesueur, 1818) } \\
\text { Harengula clupeola (Cuvier, 1829) }\end{array}$ & 46 \\
\hline Engraulidae & Atlantic anchoveta & & Cetengraulis edentulus (Cuvier, 1829) & \\
\hline Pinguipedidae & Namorado sandperch & Namorado & $\begin{array}{l}\text { Pseudopercis numida Miranda Ribeiro, } \\
1903\end{array}$ & 35 \\
\hline $\begin{array}{l}\text { Trichiuridae } \\
\text { Mugilidae }\end{array}$ & $\begin{array}{l}\text { Largehead hairtail } \\
\text { Lebranche mullet }\end{array}$ & $\begin{array}{l}\text { Peixe-esnada } \\
\text { Tainha }\end{array}$ & $\begin{array}{l}\text { Trichiurus lenturus Linnaeus. } 1758 \\
\text { Mugil liza Valenciennes in Cuvier and } \\
\text { Valenciennes } 1836\end{array}$ & 26 \\
\hline Scombridae & Chub mackerel & Cavalinha & Scomber ianonicus Houttuvn. 1782 & 20 \\
\hline $\begin{array}{l}\text { Corvnhaenidae } \\
\text { Carangidae }\end{array}$ & Common dolnhinfish & Dourado & Corvnhaena hinnurus Linnaeus. 1758 & 18 \\
\hline Monacanthidae & Unicorn filefish & Raduete & $\begin{array}{l}\text { Caranx hinpos (linnaeus. I/66) } \\
\text { Aluterus monoceros (Linnaeus. 1758) }\end{array}$ & $\frac{15}{11}$ \\
\hline Scombridae & Atlantic Bonito & Serra & Sarda sarda (Bloch. 1793) & 11 \\
\hline Triakidae & $\begin{array}{l}\text { Tope shark/School } \\
\text { Shark/ Sweet William }\end{array}$ & & Galeorhinus galeus (Linnaeus, 1758) & \\
\hline Carcharhinidae & Blue shark & Cação in general & Prionace glauca (Linnaeus, 1758) & 10 \\
\hline Triakidae & Dusky smooth-hound & & Mustelus canis (Mitchill, 1815) & \\
\hline Sparidae & Red porgy & Pargo & Pagrus pagrus (Linnaeus, 1758) & 10 \\
\hline Priacanthidae & Atlantic bigeye & $\begin{array}{l}\text { Mirassol/Olho-de- } \\
\text { cão/olhudo }\end{array}$ & Priacanthus arenatus Cuvier, 1829 & 10 \\
\hline
\end{tabular}




\begin{tabular}{|c|c|c|c|c|}
\hline Epinephelidae & $\begin{array}{l}\text { Comb grouper } \\
\text { Dusky grouper } \\
\text { Black grouper } \\
\text { Gag }\end{array}$ & Garoupa in general & $\begin{array}{l}\text { Mycteroperca } \\
\text { acutirostris (Valenciennes, 1828) } \\
\text { Epinephelus marginatus (Lowe, 1834) } \\
\text { Perca bonaci (Poey, 1860) } \\
\text { Mycteroperca microlepis (Goode \& } \\
\text { Bean, 1879) }\end{array}$ & 8 \\
\hline \multirow[t]{2}{*}{ Carangidae } & Lesser amberjack & & Seriola fasciata (Bloch, 1793) & \\
\hline & Yellowtail amberjack & Olhete in general & $\begin{array}{l}\text { Seriola lalandi Valenciennes in Cuvier \& } \\
\text { Valenciennes } 1833\end{array}$ & 8 \\
\hline Polyprionidae & Wreckfish & & $\begin{array}{l}\text { Polyprion americanus (Bloch \& } \\
\text { Schneider, 1801) }\end{array}$ & \\
\hline $\begin{array}{l}\text { Epinephelidae } \\
\text { Epinephelidae }\end{array}$ & $\begin{array}{l}\text { Yellowedge grouper } \\
\text { Snowy grouper }\end{array}$ & Cherne in general & $\begin{array}{l}\text { Hyporthodus flavolimbatus (Poey, 1865) } \\
\text { Hyporthodus niveatus (Valenciennes, } \\
1828 \text { ) }\end{array}$ & 7 \\
\hline
\end{tabular}

\section{Conservation status of the most critical fishing targets - IUCN Red List}

According to the information on the IUCN Red List Category Assessment and IUCN Criteria (Table 5), the Bluefish Pomatomus saltatrix (Linnaeus, 1766) is classified as Vulnerable (VU) with a declining population trend. $P$. saltatrix is a continental shelf species with high migration power, distributed in both hemispheres specifically in subtropical and warm-temperate regions (JUANES et al., 1996). This marine pelagic species in this study was the most cited by artisanal fishers $(79.1 \%)$ as a target of the local fishing in Arraial do Cabo. This data goes according to the findings in the literature that evidences bluefish as a highly relevant fishing resource for artisanal fishing in Southeastern Brazil (Souza et al. 2019). Besides, the bluefish represents a large part of the landings of the fishing village of Arraial do Cabo (CUMPLIDO et al., 2018), which further reinforces the importance of this species to the local economy and consequently fishing pressure. Nevertheless, it is also essential to point out that this species meets the vulnerable population (IUCN Red List) globally, and in Brazil biological data and regular monitoring of the stocks of this artisanal fishery are scarce, which makes this type of fisher's ecological knowledge an auxiliary tool crucial for bluefish conservation (SILVANO and BEGOSSI, 2009). The fact that the population of this species has a history of fluctuation in population abundance (JUANES et al., 2002), it is advisable to try to understand the practices carried out by the bluefish fishery in local communities such as Arraial do Cabo. This procedure will be able to assist and place efficient mitigation measures together with the fishing villages in favor of this species of the high socio-economic importance of the Brazilian coast.

The squids, D. (Doryteuthis) plei and D. sanpaulensis, have not yet been evaluated for IUCN red list. C. latus, S. japonicus, C. hippurus, C. hippos, S. sarda are classified as Least Concern (LC), with a stable population at this time. The species of bonito in general ( $K$. pelamis, A. thazard and $E$. alletteratus), $P$. numida, T. lepturus were also classified as Least Concern (LC) and with a stable population trend. P. pagrus, P. arenatus and A. monoceros are classified as Least Concern (LC), with unknown population data. M. liza presents Deficient Data (DD) in conservation status and unknown population trends (Table 5).

Among the sardines landed in the state of Rio de Janeiro, S. brasiliensis has not yet been evaluated for the IUCN Red List (FIPERJ, 2015). The species $O$. oglinum and $C$. sedentulus were attributed by IUCN as Least Concern (LC), with an unknown population trend. Finally, H. clupeola was classified as Least concern (LC), but with a tendency of population decline.

Among the groupers in general, M. acutirostris is classified as Least Concern (LC) with a stable population. Epinephelus marginatus (Lowe, 1834), presents the conservation status Vulnerable (VU), and with decreasing tendency of their fish stocks. The Dusk Grouper, E. marginatus is a marine neritic and intertidal species (IUCN 2019), present along the Southwest Atlantic coast (Uruguay, Argentina, and Southeast Brazil), the British Isles and the Sea Mediterranean, and finally along the coast of Africa to Mozambique (CONDINI et al., 2015). This demersal species exhibits considerable ecological and economic importance in all places of occurrence (MELLO et al., 2018). In Brazil, this reef fish is a vital source of food for fishing villages, contributing decisively to the food security of many poor coastal populations in South America (BEGOSSI et al., 2016). In Arraial do Cabo, this species was mentioned eight times as targeting of this artisanal tropical fishery. Although a limited 
number of mentions to this target fish, it does not necessarily mean that other fishers in the region cannot capture it. All attention must be paid to this grouper that in recent years has been suffering from the excessive exploitation of predatory and commercial fishing, and its peculiar reproductive traits that contribute to its population decline (CABALEIRO et al., 2018). We emphasize here the importance of the local ecological knowledge of fishers to provide and assist in the management of species with some degree of population decline in regions where biological scientific data on fish are scarce (SILVANO et al., 2006). This fact occurs with dusk grouper, where data on reproductive biology are still insufficient in Brazil (ANDRADE et al., 2003).

Table 5. Target marine species of the artisanal fishery of Arraial do Cabo, Rio de Janeiro State, Brazil, and the state of conservation according to the IUCN Red List of Threatened Species and the National List of Brazilian Fauna Species Threatened by Extinction.

\begin{tabular}{|c|c|c|}
\hline $\begin{array}{l}\text { Fisher's target species in Arraial do } \\
\text { Cabo }\end{array}$ & IUCN Conservation status & $\begin{array}{l}\text { National List of Brazilian Fauna Species } \\
\text { Threatened by Extinction }\end{array}$ \\
\hline Pomatomus saltatrix & Vulnerable (VU) & Near Threatened - Quase ameaçada (NT) \\
\hline Doryteuthis (Doryteuthis) pleii & Not Evaluated (NE) & Not included \\
\hline Doryteuthis sanpaulensis & Not Evaluated (NE) & Not included \\
\hline Caranx latus & Least Concern (LC) & Least Concern - Pouco preocupante (LC) \\
\hline Katsuwonus pelamis & Least Concern (LC) & Least Concern - Pouco preocupante (LC) \\
\hline Auxis thazard & Least Concern (LC) & Least Concern - Pouco preocupante (LC) \\
\hline Euthynnus alletteratus & Least Concern (LC) & Least Concern - Pouco preocupante (LC) \\
\hline Sardinella brasiliensis & Not Evaluated (NE) & Date Deficient - Dados Deficientes (DD) \\
\hline Opisthonema oglinum & Least Concern (LC) & Least Concern - Pouco preocupante (LC) \\
\hline Harengula clupeola & Least Concern (LC) & Least Concern - Pouco preocupante (LC) \\
\hline Cetengraulis edentulus & Least Concern (LC) & Least Concern - Pouco preocupante (LC) \\
\hline Pseudopercis numida & Least Concern (LC) & Near Threatened - Quase ameaçada (NT) \\
\hline Trichiurus lepturus & Least Concern (LC) & Least Concern - Pouco preocupante (LC) \\
\hline Mugil liza & Deficient Data (DD) & Near Threatened - Quase ameaçada (NT) \\
\hline Scomber japonicus & Least Concern (LC) & Not included \\
\hline Coryphaena hippurus & Least Concern (LC) & Not included \\
\hline Caranx hippos & Least Concern (LC) & Least Concern - Pouco preocupante (LC) \\
\hline Aluterus monoceros & Least Concern (LC) & Near Threatened - Quase ameaçada (NT) \\
\hline Sarda sarda & Least Concern (LC) & Least Concern - Pouco preocupante (LC) \\
\hline Galeorhinus galeus & Vulnerable (VU) & $\begin{array}{l}\text { Critically Endangered - Criticamente em Perigo } \\
\text { (CR) }\end{array}$ \\
\hline Prionace glauca & Near Threatened (NT) & Near Threatened - Quase ameaçada (NT \\
\hline Mustelus canis & Near Threatened (NT) & Endangered - Em Perigo (EN) \\
\hline Pagrus pagrus & Least Concern (LC) & Date Deficient - Dados Deficientes (DD) \\
\hline Priacanthus arenatus & Least Concern (LC) & Not included \\
\hline Mycteroperca acutirostris & Least Concern (LC) & Date Deficient - Dados Deficientes (DD) \\
\hline Epinephelus marginatus & Vulnerable (VU) & Vulnerable - Vulnerável (VU) \\
\hline Mycteroperca bonaci & Near Threatened (NT) & Vulnerable - Vulnerável (VU) \\
\hline Mycteroperca microlepis & Least Concern (LN) & Date Deficient - Dados Deficientes (DD) \\
\hline Seriola fasciata & Least Concern (LC) & Date Deficient - Dados Deficientes (DD) \\
\hline Seriola lalandi & Least Concern (LC) & Least Concern - Pouco preocupante (LC) \\
\hline $\begin{array}{l}\text { Polyprion americanus } \\
\text { Subpopulation }\end{array}$ & Critically Endangered (CR) & $\begin{array}{l}\text { Critically Endangered - Criticamente em Perigo } \\
(\mathrm{CR})\end{array}$ \\
\hline Hyporthodus flavolimbatus & Vulnerable (VU) & Date Deficient - Dados Deficientes (DD) \\
\hline Hyporthodus niveatus & Vulnerable (VU) & Vulnerable - Vulnerável (VU) \\
\hline
\end{tabular}


Mycteroperca bonaci (Poey, 1860) shows up the Near Threatened (NT) with declining population. It is a large Epinephelid known as black grouper (IUCN, 2019). This piscivorous species inhabits coral reefs and rocky ledges and is found from Bermuda and Massachusetts to Southeastern Brazil (South America to Santa Catarina, and the Trindade and Fernando de Noronha Islands), including the Southern Gulf of Mexico, the Florida Keys, Bahamas, Cuba, and the Caribbean (CRABTREE and BULLOCK, 1998; TEIXEIRA et al., 2004; IUCN, 2019). In the present research conducted in Arraial do Cabo, artisanal fishers mentioned this species eight times as being the target of local fishing. According to global biological data (IUCN) and local data of this species (Brazilian Red List), there is evidence of a decline in its stocks. Bender et al. (2014) on the same line showed a trend of the population decline of species of the Epinephelidae family through ethnobiological data of fishers and underwater visual census campaigns in tropical reef areas in Arraial do Cabo. In this list were included species such as E. marginatus, Mycteroperca bonaci and M. acutirostris and M. microlepis, which we will discuss later. As in our findings, Bevilacqua et al. (2016) also mentioned the black grouper as one of the most captured fish species in Rio Grande do Norte State (Brazilian northeast coast). M. bonaci was also presented as the second most exploited or threatened species of groupers of a crucial area of coral reefs in the South Atlantic (GIGLIO et al., 2018). From this perspective, any palliative measure concerning the conservation of this species is essential, since only formal fisheries regulations are not sufficient (IUCN, 2019). Finally, regional data from the fishing community may collaborate to assist measures and warn about overfishing of this species of grouper mainly in reef areas in the tropical Atlantic locally in conjunction with the population.

Mustelus canis (Mitchill, 1815) and P. glauca are also classified as Near Threatened (NT) but with current population trend unknown. M. canis is a species of the Triakidae Family, which presents distribution in southern Brazil (FROESE and PAULY, 2019). This shark species is highly susceptible to overfishing because it is a typically $\mathrm{K}$ strategist species with low fertility rate, late sexual maturity, and long generation time (BITALO et al., 2015). Artisanal fisheries are one of the main responsible for the population declines of Mustelus worldwide with a considerable prominence for South America, where the impact is even more intense (TAGLIAFICO et al., 2017). According to data from the IUCN and the Brazilian Red List this species is classified consecutively as Near Threatened (NT) and in Endangered (EN), which makes the conservation status of these sharks very worrisome. This same species was cited ten times as a target of artisanal fishing, which may generate some impact for the effective implementation of measures of local preservation of $M$. canis in Arraial do Cabo. Considering the lack of adequate infrastructure in developing countries, one of the possibilities for problems of this scope would be to find a conservationist practice according to the specificity of each species, stock, location, and fishing activity together with a variety of different and complementary policy tools for such success. The complementarity of actions in the region of Arraial do Cabo already used should be readjusted according to local conservation and management policy, instead of being changed (HOYT, 2014; SHIFFMAN and HAMMERSCHLAG, 2016), which can change the attitudes of the fishermen positively.

According to the information provided by the local fishers in Arraial do Cabo, it was possible to identify eight marine species that present some degree of vulnerability by the IUCN. One of them, $P$. glauca (Blue shark), has already been mentioned in the list of species with some degree of threat of the Portuguese community, which reinforces, even more, the tendency of predation and the population decline of this species in worldwide. Hyporthodus flavolimbatus (Poey, 1865), Hyporthodus niveatus (Valenciennes, 1828), and Galeorhinus galeus (Linnaeus, 1758) are listed as Vulnerable (VU) with declining populations (Table 5). H. flavolimbatus is distributed in Brazil from $12^{\circ} \mathrm{S}$ to the state of Rio Grande do Sul (ROBERTSON and VAN TASSELL, 2015). Yellowedge grouper (Pisces: Epinephelidae) is characterized by being a bycatch on longline or in the gillnet fisheries of other target fish. However, most of the time, this grouper is the target of longline fishing (IUCN 2016). General characteristics of the assemblage of groupers such as slow growth, long life, and large size, make these species predisposed to overexploitation by fishing around the world (COOK et al., 2009). IUCN Red List database indicates $H$. flavolimbatus with current and markedly historical fishing pressure, and with Vulnerable (VU) status (decreasing population) (IUCN, 2019). In Arraial do Cabo this species was mentioned seven times as belonging to the target species of artisanal fishing in the region. Miloslavich et al. (2011) argue about the exploitation by local populations of species of commercial value in the tropical West Atlantic and cite Yellowedge grouper as one of the most important species for artisanal fisheries in this region. At this point, it becomes vital to understand the circumstances 
under which the fishers of Arraial do Cabo are capturing this species to better understand the inclusion of the species as a target for artisanal fisheries.

$H$. niveatus is a marine neritic species from the family Epinephelidae and is primarily distributed in the Western Atlantic from Massachusetts (United States) to South America (southern Brazil and Uruguay) (HEEMSTRA and RANDALL, 1993; CRAIG et al., 2011). At a current global level, this grouper was considered Vulnerable (IUCN, 2019). In 2014 this species was already present in the Brazilian National List and was considered Overexploited (OE), and currently is still included as Vulnerable (VU) (ICMBio 2018). Fishers from Arraial do Cabo cited this grouper seven times as being the target of local artisanal fishing. Lima and contributors (2019) in the north coast of Rio de Janeiro also reported this grouper belonging to the primary fishing group of the village of Guaxindiba. Even though it is mentioned less often, it is essential to monitor the management actions of this local fishery, as well as the national programs of conservation of this species (MOTTA et al., 2014), given the vulnerability of $H$. niveatus stocks. Further research into the structure of independent populations of groupers, and better protection of the male population and juvenile and immature catches are indispensable at this moment to the conservation of this Epinephelid species (IUCN, 2019).

G. galeus is a shark-school of the Triakidae family with a cosmopolitan distribution specifically on the shelf and temperate coastal waters (EBERT et al., 2013). This species of shark is commercially significant where it is fished, mainly for the excellent quality of meat that it has, and the variety of parts used of this species for human consumption (FAO, 2019). Although this particularity, the existence of limited data of this species frequently makes it confused with other species with some degree of similarity in the fishing sites (BESTER-VAN DER MERWE et al., 2017). In Arraial do Cabo, the top shark was mentioned ten times by artisanal fishers as a target species for local fishing. From a certain point of view, this can be worrisome when we observe this species classified as Vulnerable (VU) by the IUCN (IUCN, 2019) and Critically Threatened (CR) locally on the Brazilian coast (ICMBio, 2018). On the other hand, it is essential to point out this possible confusion of species identification that may come to exist about G. galeus in the region of Arraial do Cabo. In accordance with Barbosa-Filho et al. (2014), we also suggest investigating the local ecological knowledge (including ethnotaxonomy) of fishing in the Brazilian coast as a way of assisting the National Action Plan for the Conservation of Shark Species. This fact is mainly due to the limitation of fishery data and the financial resources for research in developing countries.

M. microlepis presents as Least Concern (LC) according to the IUCN Red List. About the species of Olhete, S. fasciata and S. lalandi were grouped as Least Concern (LC) with populations respectively unknown and stable. Among Cherne species, P. americanus showed Date Deficient (DD) with unknown population (Table 5). Even with the current observed trend, we suggest the constant monitoring of the stocks of these species both at a global and regional level.

\section{Conservation status of the most critical fishing targets - Brazilian Red Book}

The species cited by artisanal fishers belonging to the village of Arraial do Cabo in Brazil were also analyzed following the Brazil Red Book of Threatened Species of Fauna (ICMBIO, 2018). Fishers cited twenty-eight target species that make up this Brazilian Red List (Table 5). C. latus, $K$. pelamis, A. thazard, E. alletteratus, O. oglinum, H. clupeola, C. edentulous, T. lepturus, C. hippos, $S$. sarda, S. lalandi were considered as the Least Concern (LC). On the other hand, P. saltatrix, $P$. numida, M. liza, A. monoceros, and $P$. glauca were considered as Near Threatened (NT). The species E. marginatus, $M$. bonaci and $H$. niveatus had their populations classified as Vulnerable (VU). $M$. canis assessed as Endangered (CR). G. galeus and P. americanus - Brazilian subpopulations - are considered as Critically Endangered (CR). S. brasiliensis, P. pagrus, M. acutirostris, M. microlepis, $S$. fasciata and $H$. flavolimbatus showed Date Deficient (DD). The remaining species were not present in this last National List of Species of the Brazilian Fauna Threatened of Extinction made available by the Brazilian Government.

\section{Species from Brazilian Red Book}

The species classified with some degree of vulnerability (Near Threatened, Endangered or Critically Endangered; Table 5) in Brazil that were cited by artisanal fishers as a target fishery in Arraial do Cabo should be analyzed succinctly and together with managers and the participation of villages. Also included in this topic are the species cited by fishers with insufficient data on the state of conservation of stocks. 
Fishery data from the local social dimension have been applied to tropical ecosystems as a way of assessing the exploitation of natural resources as well as supporting biodiversity conservation initiatives (HALLWASS, SCHIAVETTI and SILVANO, 2019). This type of approach for coastal regions is advisable because they have probably already experienced failures in conservation and fisheries sustainability primarily because they considered the uncertainty of socio-ecological systems or even the necessary conservation data were not available (LIU and CHANG, 2019).

These fishing resources cited as target fishing in Arraial do Cabo are usually caught by numerous fishing methods and in an unsustainable way. Therefore, they should be monitored efficiently to avoid being depleted on the coast of Rio de Janeiro. Constant monitoring, restrictions on these species, and the introduction of new technologies to minimize bycatch become crucial to maintaining biodiversity (ROTUNDO et al., 2019). The public political fragility interconnected within the area of the Arraial do Cabo Extractive Reserve, which affects the protection of biological resources, also becomes a significant obstacle to the sustainability of fishing within this Conservation Unit (CARDOSO and DOULA, 2018).

We call attention here to the Brazilian subpopulation of Polyprion americanus, as it is Critically Threatened (CR) both in the IUCN Red List and in the Red List of Threatened Species and the National List of Threatened Brazilian Species of Extinction. P. americanus biomass has decreased dramatically in Brazil, and the remaining fish population remains under heavy fishing pressure in breeding areas, which can lead to a rapid collapse of its stock (HAIMOVICI and PERES, 2005). Finally, maintaining the interruption of catches for the preservation and recovery of fish stocks and the dialogue without conflicts of interest with the community of Arraial do Cabo on fishing emerges as the best strategy to try to reveal the current conservation framework of this species.

\section{CONCLUSION}

This LEK survey of two fishing villages was carried out to discover the target species of artisanal fishing. Our results may be closely linked to the experiences acquired and the baseline of the local fisheries, as well as in the visualizations of the daily changes of the fishing trips in each analyzed region. Both fishing communities analyzed in Brazil (Inside the Arraial do Cabo Marine Reserve) and Portugal (Near the Berlengas Nature Reserve) showed a variety of fish species as part of the local target fishery.

We also highlight artisanal fishing pressure on European pilchard - Sardina pilchardus, Horse mackerel - Trachurus trachurus, Chub mackerel - Scomber japonicus, and Conger eel - Conger conger in Peniche village, Portugal. In Arraial do Cabo, Brazil, we highlight a more significant fishing effort in the possible following target species: Bluefish - Pomatomus saltatrix, two species of squids Doryteuthis (Doryteuthis) pleii and Doryteuthis sanpaulensis, and Horse-eye jack - Caranx latus. We also highlight three species of tuna - Katsuwonus pelamis, Auxis thazard, and Euthynnus alletteratus, and species of sardines in general - Sardinella brasiliensis, Opisthonema oglinum, Harengula clupeola and Cetengraulis edentulous, and Namorado Sandperch - Pseudopercis numida.

We conducted analyses, updates and discussed the main target species of the two fishing communities with some degree of vulnerability on the IUCN Red List of Threatened Species for scientific and ecological purposes. In Peniche were T. trachurus and P. glauca. In Arraial do Cabo were $P$. saltatrix, E. marginatus, $M$. bonaci, $P$. glauca, M. canis, $H$. flavolimbatus, $H$. niveatus, $G$. galeus and P. americanus - Brazilian subpopulation. This survey of species targeted at different areas and by different fishers becomes crucial as it may have the ability to identify populations of species that are at risk of being extirpated or that may be further explored (PURCELL et al., 2018).

In the traditional Atlantic communities studied we call attention to the species that are still targeted by the artisanal fisheries currently with some degree of vulnerability, with insufficient data and lack of data evaluated by the IUCN or the Brazilian list of endangered species. Given the difficulties of managing the monitoring of fisheries on the Brazilian coast, studies of low cost and which can generate data in real-time and in a fast way like this can collaborate as another source of data about the local artisanal fishery. This Fishers' LEK, according to Lopes et al. (2018), becomes a viable database in developing countries such as Brazil, which lacks resources for ecological research in modern times and has urgent conservation needs (LOPES et al., 2018; THOMÉ and HADDAD, 2019). Besides, with such data, species preservation can also be aided, as this information source from local communities can contribute to generating testable hypotheses for future ecological studies (DREW, 2005) in both fishing villages (Brazil and Portugal). Fishers' LEK shown in this present research can be used as a 
potential auxiliary tool for collaboration in the management of the species on intense fishing pressure in these two villages inserted in protected areas of great economic and cultural importance to the Atlantic system. The shared results can be interesting for an adaptive management that integrates all stakeholders in socio-ecological management experiments. The LEK recognition of the actors involved may contribute to the ecological literacy of users and develop an environmental concern to move towards sustainability (FUJITANI et al., 2017).

\section{ACKNOWLEDGMENTS}

Firstly, we thank the fishing villages of Peniche and Arraial do Cabo for their significant contribution to our work. We also thank the Research Ethics Committee of the Federal University of Rio de Janeiro, Brazil, for the approval of this research, and to ICMBIO Brazil for the authorization to perform scientific activities within the Marine Conservation Unit of Arraial do Cabo. We are grateful for the fundamental participation of Rayza Cruz and Tayara Carlos in this study. Thanks are due for the financial support to CESAM, to FCT/MCTES through national funds (UIDB/50017/2020+UIDP/50017/2020), and the co-funding by the FEDER, within the PT2020 Partnership Agreement and Compete 2020. Braga H.O be grateful to the CAPES Foundation Ministry of Education of Brazil (BEX: 8926/13-1), and the Project ReNATURE - Valorization of the Natural Endogenous Resources of the Centro Region (Centro 2020; Centro-01-0145-FEDER-00000 Center for Functional Ecology - CFE, Department of Life Sciences, University of Coimbra, Portugal). Musiello-Fernandes J. thanks to the CAPES Foundation ( $\mathrm{n}^{\circ} 88882315888$ / 2019-1 - financing code, 001) for the granting of a post-doc scholarship.

\section{REFERENCES}

ABAUnZA, P.; MURTA, A. G.; CAMPBEll, N.; CIMMARUTA, R.; COMESAÑA, A. S.; DAHLE, G.; SANTAMARÍA, M. G.; GORDO, L. S.; IVERSEN, S. A.; MACKENZIE, K.; OTHERS. Stock identity of horse mackerel (Trachurus trachurus) in the Northeast Atlantic and Mediterranean Sea: Integrating the results from different stock identification approaches. Fisheries Research, [s. 1.], v. 89, n. 2, p. 196-209, 2008.

ABREU, J. S.; DOMIT, C.; ZAPPES, C. A. Is there dialogue between researchers and traditional community members? The importance of integration between traditional knowledge and scientific knowledge to coastal management. Ocean \& Coastal Management, [s. 1.], v. 141, p. 10-19, 2017.

ALBUQUERQUE, U. P.; LUCENA, R. F.; CUNHA, L. V.; ALVES, R. R. N. Methods and techniques in ethnobiology and ethnoecology. New York: Springer, 2014. Disponível em: <Métodos e técnicas para a coleta de dados etnobiológicos.>

ALLISON, E. H.; ELLIS, F. The livelihoods approach and management of small-scale fisheries. Marine Policy, [s. 1.], v. 25, n. 5, p. 377-388, 2001.

ALVES, L. M. F.; NUNES, M.; MARCHAND, P.; LE BIZEC, B.; MENDES, S.; CORREIA, J. P. S.; LEMOS, M. F. L.; NOVAIS, S. C. Blue sharks (Prionace glauca) as bioindicators of pollution and health in the Atlantic Ocean: Contamination levels and biochemical stress responses. Science of The Total Environment, [s. 1.], v. 563-564, p. 282-292, 2016.

ALVES, R.; SOUTO, W. Ethnozoology: A Brief Introduction. Ethnobiology and Conservation, [s. 1.], 2015. Disponível em: <http://www.ethnobioconservation.com/index.php/ebc/article/view/63/60>. Acesso em: 25 jun. 2019.

AWABDI, D. R.; TAVARES, D. C.; BONDIOLI, A. C. V.; ZAPPES, C. A.; DI BENEDiTTO, A. P. M. Influences of conservation action on attitudes and knowledge of fishermen towards sea turtles along the southeastern Brazil. Marine Policy, [s. 1.], v. 95, p. 57-68, 2018.

BÉNÉ, C. Small-scale fisheries: assessing their contribution to rural livelihoods in developing countries. FAO fisheries circular, [s. 1.], v. 1008, p. 46, 2006.

BERKES, F.; COLDING, J.; FOLKE, C. Navigating social-ecological systems: building resilience for complexity and change. [s.l.] : Cambridge University Press UK, 2008.

BEVILACQUA, A. H. V.; CARVALHO, A. R.; ANGELINI, R.; CHRISTENSEN, V. More than Anecdotes: Fishers' Ecological Knowledge Can Fill Gaps for Ecosystem Modeling. PLOS ONE, [s. 1.], v. 11, n. 5, p. e0155655, 2016.

BIRÓ, É.; BABAI, D.; BÓDIS, J.; MOLNÁR, Z. Lack of knowledge or loss of knowledge? Traditional ecological knowledge of population dynamics of threatened plant species in East-Central Europe. Journal for Nature Conservation, [s. 1.], v. 22, n. 4, p. 318-325, 2014.

BITALO, D. N.; MADUNA, S. N.; DA SILVA, C.; ROODT-WILDING, R.; BESTER-VAN DER MERWE, A. E. Differential gene flow patterns for two commercially exploited shark species, tope (Galeorhinus galeus) and common smoothhound (Mustelus mustelus) along the south-west coast of South Africa. Fisheries Research, [s. 1.], v. 172, p. 190-196, 2015.

BRAGA, H. O.; AZEITEIRO, U. M.; OLIVEIRA, H. M. F.; PARDAL, M. A. Evaluating fishermen's conservation attitudes and local ecological knowledge of the European sardine (Sardina pilchardus), Peniche, Portugal. Journal of Ethnobiology and Ethnomedicine, [s. 1.], v. 13, n. 1, p. 25, 2017. 
BRAGA, H. O.; PARDAL, M. Â.; AZEITEIRO, U. M. Incorporation of Local Ecological Knowledge (LEK) into Biodiversity Management and Climate Change Variability Scenarios for Threatened Fish Species and Fishing Communities-Communication Patterns Among BioResources Users as a Prerequisite for Co-management: A Case Study of Berlenga MNR, Portugal and Resex-Mar of Arraial do Cabo, RJ, Brazil. In: LEAL FILHO, W.; MANOLAS, E.; AZUL, A. M.; AZEITEIRO, U. M.; MCGHIE, H. (Eds.). Handbook of Climate Change Communication: Vol. 2. Cham: Springer International Publishing, 2018b. p. 237-262.

BRAGA, H. O.; PARDAl, M. Â.; CRUZ, R. C. M. Da; AlvarEnGA, T. C.; AZEITEIRO, U. M. Fishers' knowledge in Southeast Brazil: The case study of the Brazilian sardine. Ocean \& Coastal Management, [s. 1.], v. 165, p. 141-153, 2018a.

BRAGA, H. O.; PEREIRA, M. J.; MORGADO, F.; SOARES, A. M. V. M.; AZEITEIRO, U. M. Ethnozoological knowledge of traditional fishing villages about the anadromous sea lamprey (Petromyzon marinus) in the Minho river, Portugal. Journal of Ethnobiology and Ethnomedicine, [s. 1.], v. 15, n. 1, p. 71, 2019.

BROOK, R. K.; MCLACHLAN, S. M. Trends and prospects for local knowledge in ecological and conservation research and monitoring. Biodiversity and Conservation, [s. 1.], v. 17, n. 14, p. 3501-3512, 2008.

CARBONEL, C. A. A. H. Modelling of upwelling-downwelling cycles caused by variable wind in a very sensitive coastal system. Continental Shelf Research, [s. 1.], v. 23, n. 16, p. 1559-1578, 2003.

CARDOSO, P. O.; DOULA, S. M. Reservas extrativistas marinhas: perspectivas e limitações para jovens pescadores. Acta Biológica Catarinense, [s. 1.], v. 5, n. 2, p. 5, 2018.

COSTA-NETO, E. M.; MARQUES, J. G. W. Conhecimento ictiológico tradicional ea distribuição temporal e espacial de recursos pesqueiros pelos pescadores de Conde, Estado da Bahia, Brasil. Etnoecológica, [s. 1.], v. 4, n. 6, p. 56-68, 2000.

DAVIS, A.; WAGNER, J. R. Who Knows? On the Importance of Identifying "Experts" When Researching Local Ecological Knowledge. Human Ecology, [s. 1.], v. 31, n. 3, p. 463-489, 2003.

DEEPANANDA, K. H. M. A.; AMARASINGHE, U. S.; JAYASINGHE-MUDALIGE, U. K.; BERKES, F. Stilt Fisher knowledge in southern Sri Lanka as an expert system: a strategy towards co-management. Fisheries Research, [s. 1.], v. 174, p. 288-297, 2016.

DIEGUES, A. C. Etnoconservação: novos rumos para a proteção da natureza nos trópicos. second ed ed. São Paulo: Nupaub LTDA, 2000.

DOCA PESCA, S. A. Docapesca - Portos e Lotas, S.A. Departamento de Segurança Alimnetar e Certificação. Conselho de Administração. Mod. FT_SA_G_115_00. 2018. Disponível em: <https://drive.google.com/file/d/1yUQdC4f_v_g8x6WaSj6bN55gj5z-

asUl/view?fbclid=IwAR1 uvxyBaj7gpgF9FZSDDoOpvxQsNrEI7Jyp-o8FKN60ObDlcFKAzUavDG30>. Acesso em: 28 ago. 2020.

DREW, J. A. Use of Traditional Ecological Knowledge in Marine Conservation. Conservation Biology, [s. 1.], v. 19, n. 4, p. 1286-1293, 2005.

ESPINOZA-TENORIO, A.; WOLFF, M.; ESPEJEL, I.; MONTAÑO-MOCTEZUMA, G. Using Traditional Ecological Knowledge to Improve Holistic Fisheries Management: Transdisciplinary Modeling of a Lagoon Ecosystem of Southern Mexico. Ecology and Society, [s. 1.], v. 18, n. 2, p. art6, 2013.

FAO. The State of World Fisheries and Aquaculture 2018-Meeting the sustainable development goals." Licence: CC BY-NC-SA 3.0 IGO., 2018. Disponível em: 〈http://www.fao.org/3/i9540en/i9540en.pdf>. Acesso em: 27 maio. 2020.

FERNANDES, M. da L.; ANTUNES, I. C.; OLIVEIRA, E. R.; ALVES, F. L. Design Policy Options supported by Marine and Coastal Ecosystem Services Assessment and Valuation: a Case Study in Portugal. Journal of Coastal Research, [s. 1.], v. 75, n. sp1, p. 977-981, 2016.

FISCHER, J.; JORGENSEN, J.; JOSUPEIT, H.; KALIKOSKI, D. C.; FAO (EDS.). Fishers' knowledge and the ecosystem approach to fisheries: applications, experiences and lessons in Latin America. Rome.

FROESE, R.; PAULY, D. FishBase. World Wide Web electronic publication. www.fishbase.org, (12/2019). 2019. Disponível em: <https://www.fishbase.se/summary/Alosa-alosa.html>. Acesso em: 31 mar. 2020.

FUJITANI, M.; MCFALL, A.; RANDLER, C.; ARLINGHAUS, R. Participatory adaptive management leads to environmental learning outcomes extending beyond the sphere of science. Science Advances, [s. 1.], v. 3, n. 6, p. e1602516, 2017.

GIGLIO, V. J.; BENDER, M. G.; ZAPELINI, C.; FERREIRA, C. E. L. The end of the line? Rapid depletion of a large-sized grouper through spearfishing in a subtropical marginal reef. Perspectives in Ecology and Conservation, [s. 1.], v. 15, p. 115-118, 2017.

HAIMOVICI, M.; PERES, M. B. em Rossi, C.L.W. Cergole M.C. Ávila-da Silva, A.O. Análise das Principais Pescarias Comerciais da Região Sudesde-Sul do Brasil: Dinâmica Populacional das Espécies em Exploração. In: Série Documentos Revizee-Score Sul. IOUSP. p. 124-131.

HALLWASS, G.; SCHIAVETTI, A.; SILVANO, R. A. M. Fishers' knowledge indicates temporal changes in composition and abundance of fishing resources in Amazon protected areas. Animal Conservation, [s. 1.], p. acv.12504, 2019.

HARRIS, M. History and Significance of the EMIC/ETIC Distinction. Annual Review of Anthropology, [s. 1.], v. 5, n. 1, p. 329-350, 1976.

HICKS, C. C.; COHEN, P. J.; GRAHAM, N. A. J.; NASH, K. L.; ALLISON, E. H.; D'LIMA, C.; MILLS, D. J.; ROSCHER, M.; THILSTED, S. H.; THORNE-LYMAN, A. L.; MACNEIL, M. A. Harnessing global fisheries to tackle micronutrient deficiencies. Nature, [s. 1.], v. 574, n. 7776, p. 95-98, 2019. 
HOYT, E. The role of marine protected areas and sanctuaries. Sharks: conservation, governance and management, [s. 1.], p. 236-261, 2014.

ICMBIO. Instituto Chico Mendes de Conservação da Biodiversidade - ICMBio. Livro Vermelho da Fauna Brasileira Ameaçada de Extinção (Executive Summary - Brazil Red Book of Threatened Species of Fauna). 1. ed. Brasília - DF: ICMBio/MMA, 2018. v. 1 Disponível em: <http://www.icmbio.gov.br/portal/images/stories/comunicacao/publicacoes/publicacoes-

diversas/livro_vermelho_2018_vol1.pdf>. Acesso em: 29 ago. 2018.

ICMBIO. Instituto Chico Mendes de Conservação da Biodiversidade. DECRETO DE 3 DE JANEIRO DE 1997. Dispõe sobre a criação da Reserva Extrativista Marinha do Arraial do Cabo, no Município de Arraial do Cabo, Estado do Rio de Janeiro, e dá outras providências. 2019. Disponível em: <http://www.icmbio.gov.br/portal/unidadesdeconservacao/biomas-brasileiros/marinho/unidades-de-conservacaomarinho/2282-resex-marinha-do-arraial-do-cabo>. Acesso em: 21 mar. 2018.

INE, I. Estatísticas da Pesca 2013. Edição 2014. Instituto Nacional de Estatística (INE) e Direção-Geral de Recursos Naturais, Segurança e Serviços Marítimos (DGRM)., Instituto Nacional de Estatística, I.P., 2014. Disponível

<https://www.ine.pt/ngt_server/attachfileu.jsp?look_parentBoui=217820764\&att_display=n\&att_download=y>

em:

INE, I. Estatísticas da Pesca 2017. Edição 2018. Instituto Nacional de Estatística (INE) e Direção-Geral de Recursos Naturais, Segurança e Serviços Marítimos (DGRM). Portugal: Instituto Nacional de Estatística, I.P., 2018. em: <https://www.ine.pt/ngt_server/attachfileu.jsp?look_parentBoui=331310314\&att_display=n\&att_download=y > Acesso em: 20 abr. 2020.

ITIS. ITIS. The Integrated Taxonomic Information System on-line database. 2018. Disponível em: $<$ http://www.itis.gov>. Acesso em: 22 mar. 2018.

IUCN. The IUCN Red List of Threatened Species. Version 2019-1. Downloaded on 05 May 2019. 2019. Disponível em: <http://www.iucnredlist.org>. Acesso em: 8 jan. 2019.

JOHANNES, R. E.; FREEMAN, M. M. R.; HAMILTON, R. J. Ignore fishers' knowledge and miss the boat. Fish and Fisheries, [s. 1.], v. 1, n. 3, p. 257-271, 2008.

LIU, T.-M.; CHANG, S.-K. Changes in local knowledge and its impacts on ecological resources management: The case of flyingfish culture of the Tao in Taiwan. Marine Policy, [s. 1.], v. 103, p. 74-83, 2019.

LOPES, P. F. M.; VERBA, J. T.; BEGOSSI, A.; PENNINO, M. G. Predicting species distribution from fishers' local ecological knowledge: a new alternative for data-poor management. Canadian Journal of Fisheries and Aquatic Sciences, [s. 1.], p. 1-9, 2018.

MARQUES, J. G. W. Pescando pescadores: Ciência e Etnociência em uma Perspectiva Ecológica. São Paulo: USP/NUPAUB, [s. 1.], p. 258p, 2001.

MARTINS, L. M. Antunes. "By-catch de espadarte (Xiphias gladius) e tintureira (Prionace glauca) juvenil no palangre de superfície”. 2013. Dissertação de Mestrado em Estudos Integrados dos Oceanos - Universidade dos Açores, Portugal, 2013. Disponível em: <https://repositorio.uac.pt/handle/10400.3/3106>. Acesso em: 9 maio. 2019.

MEDEIROS, M. C.; BARBOZA, R. R. D.; MARTEL, G.; MOURÃO, J. da S. Combining local fishers' and scientific ecological knowledge: Implications for comanagement. Ocean \& Coastal Management, [s. 1.], v. 158, p. 110,2018

MUSIELLO-FERNANDES, J.; ZAPPES, C. A.; HOSTIM-SILVA, M. Small-scale shrimp fisheries on the Brazilian coast: Stakeholders perceptions of the closed season and integrated management. Ocean \& Coastal Management, [s. 1.], v. 148, n. Supplement C, p. 89-96, 2017.

MUSIELLO-FERNANDES, J.; ZAPPES, C. A.; HOSTIM-SILVA, M. Small-scale fisheries of the Atlantic seabob shrimp (Xiphopenaeus kroyeri): Continuity of commercialization and maintenance of the local culture through making public policies on the Brazilian coast. Ocean \& Coastal Management, [s. 1.], v. 155, p. 76-82, 2018.

NYKÄNEN, M.; JESSOPP, M.; DOYLE, T. K.; HARMAN, L. A.; CAÑADAS, A.; BREEN, P.; HUNT, W.; MACKEY, M.; CADHLA, O. Ó.; REID, D.; ROGAN, E. Using tagging data and aerial surveys to incorporate availability bias in the abundance estimation of blue sharks (Prionace glauca). PLOS ONE, [s. 1.], v. 13, n. 9, p. e0203122, 2018.

OLIVEIRA JÚNIOR, J. G. C.; SILVA, L. P. S.; MALHADO, A. C. M.; BATISTA, V. S.; FABRÉ, N. N.; LADLE, R. J. Artisanal Fisheries Research: A Need for Globalization? PLOS ONE, [s. 1.], v. 11, n. 3, p. e0150689, 2016.

OLSSON, P.; FOLKE, C. Local ecological knowledge and institutional dynamics for ecosystem management: a study of Lake Racken watershed, Sweden. Ecosystems, [s. 1.], v. 4, n. 2, p. 85-104, 2001.

PAULY, D.; HILBORN, R.; BRANCH, T. A. Fisheries: Does catch reflect abundance? Nature, [s. 1.], v. 494, n. 7437, p. 303-306, 2013.

PAULY, D.; ZELLER, D. Catch reconstructions reveal that global marine fisheries catches are higher than reported and declining. Nature Communications, [s. 1.], v. 7, p. 10244, 2016.

PEÑAHERRERA-PALMA, C.; VAN PUTTEN, I.; KARPIEVITCH, Y. V.; FRUSHER, S.; LLERENAMARTILLO, Y.; HEARN, A. R.; SEMMENS, J. M. Evaluating abundance trends of iconic species using local ecological knowledge. Biological Conservation, [s. 1.], v. 225, p. 197-207, 2018.

POISSON, F.; ARNAUD-HAOND, S.; DEMARCQ, H.; MÉTRAL, L.; BRISSET, B.; CORNELLA, D.; WENDLING, B. French Bluefin Tuna Longline Fishery Bycatch Programme. In: KOMATSU, T.; CECCALDI, H.-J.; 
YOSHIDA, J.; PROUZET, P.; HENOCQUE, Y. (Eds.). Oceanography Challenges to Future Earth. Cham: Springer International Publishing, 2019. p. 401-405.

POMEROY, R.; ARANGO, C.; LOMBOY, C. G.; BOX, S. Financial inclusion to build economic resilience in small-scale fisheries. Marine Policy, [s. 1.], v. 118, p. 103982, 2020.

POMEROY, R.; PARKS, J.; POLLNAC, R.; CAMPSON, T.; GENIO, E.; MARLESSY, C.; HOLLE, E.; PIDO, M.; NISSAPA, A.; BOROMTHANARAT, S.; THU HUE, N. Fish wars: Conflict and collaboration in fisheries management in Southeast Asia. Marine Policy, [s. 1.], v. 31, n. 6, p. 645-656, 2007.

POSEY, D. Introdução - Etnobiologia: teoria e prática. In: In: RIBEIRO, B. (Ed.) Suma Etnológica Brasileira. Etnobiologia. Petrópolis: Vozes/Finep, 1987. v. 1p. 15-25.

PURCELL, S. W.; FRASER, N. J.; TAGICA, S.; LALAVANUA, W.; CECCARELLI, D. M. Discriminating Catch Composition and Fishing Modes in an Artisanal Multispecies Fishery. Frontiers in Marine Science, [s. 1.], v. 5, p. 243, 2018.

ROTUNDO, M. M.; SEVERINO-RODRIGUES, E.; BARRELLA, W.; PETRERE JUNIOR, M.; RAMIRES, M. Checklist of marine demersal fishes captured by the pair trawl fisheries in Southern (RJ-SC) Brazil. Biota Neotropica, [s. 1.], v. 19, n. 1, 2019. Disponível em: <http://www.scielo.br/scielo.php?script=sci_arttext\&pid=S167606032019000100306\&lng=en\&tlng=en>. Acesso em: 19 jun. 2019.

ROUSSEAU, Y.; WATSON, R. A.; BLANCHARD, J. L.; FULTON, E. A. Defining global artisanal fisheries. Marine Policy, [s. 1.], v. 108, p. 103634, 2019.

SANTOS, M. P. N.; SEIXAS, S.; AGGIO, R. B. M.; HANAZAKI, N.; COSTA, M.; SCHIAVETTI, A.; DIAS, J. A.; AZEITEIRO, U. M. Fisheries as a Human Activity: Artisanal Fisheries and Sustainability. Revista de Gestão Costeira Integrada, [s. 1.], v. 12, n. 4, p. 405-427, 2012.

SHIFFMAN, D. S.; HAMMERSCHLAG, N. Shark conservation and management policy: a review and primer for non-specialists. Animal Conservation, [s. 1.], v. 19, n. 5, p. 401-412, 2016.

SILVA, P.; CABRAL, H.; RANGEL, M.; PEREIRA, J.; PITA, C. Ready for co-management? Portuguese artisanal octopus fishers' preferences for management and knowledge about the resource. Marine Policy, [s. 1.], 2018. Disponível em: <http://www.sciencedirect.com/science/article/pii/S0308597X17308783>. Acesso em: 7 jan. 2019.

SILVANO, R. A. M.; BEGOSSI, A. From Ethnobiology to Ecotoxicology: Fishers' Knowledge on Trophic Levels as Indicator of Bioaccumulation in Tropical Marine and Freshwater Fishes. Ecosystems, [s. 1.], v. 19, n. 7, p. 1310$1324,2016$.

TAGLIAFICO, A.; RAGO, N.; RANGEL, S.; BROADHURST, M. K. Aspects of the reproductive biology of the data-deficient Mustelus minicanis and M. norrisi (Chondrichthyes: Triakidae) in the southern Caribbean Sea. Environmental Biology of Fishes, [s. 1.], v. 100, n. 7, p. 785-795, 2017.

TEAM, R. C. R: A language and environment for statistical computing. R version 4.0.2 (Sincere Pumpkin Patch). [s. 1.], 2020. Disponível em: <https://cran.r-project.org/src/base/R-4>. Acesso em: 28 ago. 2020.

THOMÉ, M. T. C.; HADDAD, C. F. B. Brazil's biodiversity researchers need help. Science, [s. 1.], v. 364, n. 6446, p. 1144.2-1145, 2019.

TRIMBLE, M.; JOHNSON, D. Artisanal fishing as an undesirable way of life? The implications for governance of fishers' wellbeing aspirations in coastal Uruguay and southeastern Brazil. Marine Policy, Social and cultural impacts of marine fisheries. [s. 1.], v. 37, Social and cultural impacts of marine fisheries, p. 37-44, 2013.

VANDEPERRE, F.; AIRES-DA-SILVA, A.; SANTOS, M.; FERREIRA, R.; BOLTEN, A. B.; SERRAO SANTOS, R.; AFONSO, P. Demography and ecology of blue shark (Prionace glauca) in the central North Atlantic. Fisheries Research, [s. 1.], v. 153, p. 89-102, 2014.

VERÍSSIMO, A.; SAMPAIO, Í.; MCDOWELL, J. R.; ALEXANDRINO, P.; MUCIENTES, G.; QUEIROZ, N.; SILVA, C. Da; JONES, C. S.; NOBLE, L. R. World without borders-genetic population structure of a highly migratory marine predator, the blue shark (Prionace glauca). Ecology and Evolution, [s. 1.], v. 7, n. 13, p. 47684781, 2017.

WEKKE, I. S.; CAHAYA, A. Fishermen Poverty and Survival Strategy: Research on Poor Households in Bone Indonesia. Procedia Economics and Finance, [s. 1.], v. 26, p. 7-11, 2015.

ZAPPES, C. A.; SIMÕES-LOPES, P. C.; ANDRIOLO, A.; DI BENEDITTO, A. P. M. Traditional knowledge identifies causes of bycatch on bottlenose dolphins (Tursiops truncatus Montagu 1821): An ethnobiological approach. Ocean \& Coastal Management, [s. 1.], v. 120, p. 160-169, 2016. 